\title{
Synergism of Thyroid Hormone and High Carbohydrate Diet in the Induction of Lipogenic Enzymes in the Rat
}

\author{
MECHANISMS AND IMPLICATIONS
}

\author{
Cary N. Mariash, Fran E. Kaiser, Harold L. Schwartz, Howard C. Towle, \\ and JaCk H. OPPENHEIMER, Division of Endocrinology and Metabolism, \\ Department of Medicine, University of Minnesota, Minneapolis, \\ Minnesota 55455
}

\begin{abstract}
A B S T R A C T We have investigated the relationship between the administration of triiodothyronine $\left(\mathrm{T}_{3}\right)$ and a high carbohydrate $(\mathrm{CHO})$ fat-free diet in the induction of lipogenic enzymes in two rat tissues, liver, and fat. Male thyroidectomized rats were treated with graded daily doses of $\mathrm{T}_{3}$ and either supplemented with a high $\mathrm{CHO}$ diet or left on a regular diet. Enzymes studied included malic enzyme (ME), fatty acid synthetase, glucose-6-phosphate dehydrogenase, and 6-phosphogluconate dehydrogenase. In the liver, all four lipogenic enzymes showed a synergistic response between $\mathrm{T}_{3}$ administration and high $\mathrm{CHO}$ feeding. In fat, $\mathrm{ME}$ also responded synergistically. The interaction was reflected in an increased sensitivity to $\mathrm{T}_{3}$. The dose of $\mathrm{T}_{3}$ required to achieve $50 \%$ maximal response was reduced three- to seven-fold by the high CHO diet. This phenomenon could not be attributed to a dietary-induced alteration either in $\mathrm{T}_{3}$ metabolism or in number or affinity of the $\mathrm{T}_{3}$-nuclear receptors. Moreover, studies of the relative rate of synthesis of ME suggested a simultaneous time of onset in the induction of $\mathrm{ME}$, within $2 \mathrm{~h}$ after the application of either $\mathrm{T}_{3}$ or $\mathrm{CHO}$. Thus, it is unlikely that either stimulus is secondary to the other. Since parallel experiments from this laboratory (Towle, Mariash, and Oppenheimer. 1980. Changes in hepatic levels of messenger ribonucleic acid for malic enzyme during induction by thyroid hormone or diet. Biochemistry. 19: 579-585.) show that ME induction both by $\mathrm{CHO}$ and $\mathrm{T}_{3}$ is mediated by an increase in specific messenger RNA for ME, the interaction of $\mathrm{T}_{3}$ and the dietary factor occurs at a pretranslational level.
\end{abstract}

Dr. Mariash is a recipient of National Institutes of Health Research Fellowship 1-F32-AM05880. Address reprint requests to Dr. Mariash.

Received for publication 24 July 1979 and in revised form 16 January 1980.

\section{INTRODUCTION}

Hepatic lipogenic enzymes respond in a coordinated fashion to multiple physiological stimuli (1-3). For instance, administration of a high carbohydrate $(\mathrm{CHO})^{1}$ fatfree diet results in an increase in the activity of these enzymes as a result of de novo protein synthesis $(3,4)$. In three instances increased induction has been shown to correlate with the level of polysomal messenger RNA (mRNA) (5-8). An increase in activity and mass of lipogenic enzymes also follows administration of thyroid hormone (9-12). Moreover, previous studies from our laboratory have shown that the rate of lipogenic enzyme induction is related to nuclear occupancy in a nonlinear and highly amplified fashion (13-15). Thus, in the euthyroid state when approximately one half of the nuclear sites are occupied, the rate of ME induction is less than one-tenth of that which characterizes the response when the sites are fully occupied by triiodothyronine $\left(\mathrm{T}_{3}\right)$.

The ability of these two apparently unrelated stimuli to induce the formation of the same lipogenic enzymes appears intriguing and raised fundamental questions with respect to potential interrelationships of the stimulating mechanisms. Accordingly, we undertook a systematic study to analyze the effect of $T_{3}$ on the induction of lipogenic enzymes in animals maintained on a normal chow or a high CHO diet. Four lipogenic enzymes were studied: malic enzyme (ME), fatty acid synthetase (FAS), and the two hexose monophosphate shunt enzymes, glucose-6-phosphate dehydrogenase (G6PD), and 6-phosphogluconate dehydrogenase

${ }^{1}$ Abbreviations used in this paper: CHO, carbohydrate; $\mathrm{D}_{50}$, half maximally effective dose of triiodothyronine; FAS, fatty acid synthetase; G6PD, glucose-6-phosphate dehydrogenase; ME, malic enzyme; mRNA, messenger RNA; 6PGD, 6-phosphogluconate dehydrogenase; $\mathrm{T}_{3}$, triiodothyronine. 
(6PGD). The effect of a high CHO diet on the metabolism and distribution of $T_{3}$ and specific $T_{3}$ nuclear receptor binding were assessed. Additional information was obtained from the time-course of $\mathrm{ME}$ induction by $\mathrm{T}_{3}$ or high CHO diet from serial determinations of the relative rate of synthesis of this enzyme. Our results indicate a synergistic interaction between the $T_{3}$ nuclear complex and an as yet unidentified factor generated in response to the high $\mathrm{CHO}$ diet. Our findings, furthermore, emphasize that metabolic as well as hormonal determinants can influence the expression of thyroid hormone action at a postreceptor level.

\section{METHODS}

Sprague-Dawley male rats (150-200 g) were purchased from Taconic Farms, Germantown, N. Y., and were provided with water ad lib. except where noted. Rats were rendered hypothyroid by surgical thyroidectomies performed by the supplier and the administration of $100 \mu \mathrm{Ci}$ of ${ }^{131}$ I 1 wk after the institution of a low iodine diet. Hypothyroid animals were used only after cessation of weight gain for a minimum of 2 successive wk. $\mathrm{T}_{3}$ (Sigma Chemical Co., St. Louis, Mo.) was dissolved in a minimum of $0.1 \mathrm{~N} \mathrm{NaOH}$ and made up to $2 \mathrm{mg} / \mathrm{ml}$ with distilled water. Dilutions of $\mathrm{T}_{3}$ stock solutions were made with $2 \%$ human albumin in saline. Animals were fed either a regular Purina diet (23\% protein; $55 \%$ complex CHO; $22 \%$ fat; Ralston Purina Co., St. Louis, Mo.) or a high CHO (fat-free, test diet; ICN Nutritional Biochemicals, Cleveland, Ohio; $20 \%$ casein; $60 \%$ sucrose; $20 \%$ nonabsorbable filler) which had been conventionally used in the study of lipogenic enzyme induction. Although the latter is generally referred to as a high $\mathrm{CHO}$ diet it is apparent that the percentage of total diet as CHO does not differ greatly in both diets. The high CHO diet was administered for $4 \mathrm{~d}$ because studies by others $(1,16,17)$ as well as preliminary experiments in our laboratory indicated that this period was sufficient to attain equilibrium values. In those experiments in which the time of onset was determined for high CHO, $5 \mathrm{ml}$ of $60 \%$ sucrose, $20 \%$ casein (wt/vol) was administered by gavage.

Tissue was prepared and ME was assayed as previously described $(14,18)$. G6PD and 6PGD were assayed by a modification of the technique of Bottomley et al. (19). The initial rate of reduction of NADP was followed spectrophotometrically at $30^{\circ} \mathrm{C}$ on a Beckman model 25 spectrophotometer (Beckman Instruments, Inc., Fullerton, Calif.) at $340 \mathrm{~nm}$. Each $1-\mathrm{ml}$ assay contained $120 \mu \mathrm{mol}$ Tris- $\mathrm{HCl} \mathrm{pH} 8.0,10 \mu \mathrm{mol} \mathrm{MgCl}_{2}$, $0.9 \mu \mathrm{mol}$ NADP, $0.6 \mu \mathrm{mol} 6$-phosphogluconate for the measurement of 6PGD activity or $0.6 \mu \mathrm{mol} 6$-phosphogluconate plus $2 \mu \mathrm{mol}$ of glucose-6-phosphate for the determination of combined hexose monophosphate shunt enzyme. 200-400 $\mu \mathrm{g}$ protein of the $100,000 \mathrm{~g}$ supernate was used for enzyme determination. FAS was assayed by a modification of the technique of Nepokroeff et al. (20). Immediately after centrifugation, the $100,000 \mathrm{~g}$ supernate was diluted into an equal volume of $1 \mathrm{M}$ potassium phosphate buffer, $\mathrm{pH} 7.0,10 \mathrm{mM}$ dithiothreitol. 150-300 $\mu \mathrm{g}$ protein of this solution was used for enzyme assay. The assay contained in a final volume of $1.0 \mathrm{ml} ; 200 \mu \mathrm{mol}$ potassium phosphate buffer, $\mathrm{pH} 7.0 ; 0.33 \mu \mathrm{mol}$ acetyl-CoA; 0.1 $\mu \mathrm{mol}$ malonyl-CoA; $0.1 \mu \mathrm{mol}$ NADPH; $1 \mu \mathrm{mol}$ EDTA; $1 \mu \mathrm{mol}$ 2 -mercaptoethanol. The enzyme was preincubated for $15 \mathrm{~min}$ at $37^{\circ} \mathrm{C}$ and the initial rate of reaction was followed spectrophotometrically at $340 \mathrm{~nm}$.

Enzyme activity is reported as units per milligram cytosol protein. One unit is defined as that amount of enzyme needed to catalyze the oxidation or reduction of $1 \mathrm{nmol}$ of NADP per min, using an extinction coefficient for $\mathrm{NADPH}$ of $\mathrm{E}_{340}^{\mathrm{mM}}=6.3$. All assays were linear with respect to protein concentration in the ranges used. Protein was determined by the method of Lowry et al. with bovine serum albumin as the standard (21).

ME was purified from hyperthyroid rats fed a high CHO diet by a modification of the methods of Yeung and Carrico (22). A $100,000 \mathrm{~g}$ supernatant fraction was prepared from a $20 \%$ (wt/vol) liver homogenate. A 60-80\% ammonium sulfate fraction was then adsorbed onto a $N^{6}$-(6-aminohexyl)-adenosine 2',5'-diphosphate (P-L Biochemicals, Inc. Millwauke, Wis.) affinity column. ME was eluted with $0.5 \mathrm{mM} \mathrm{NADP}{ }^{+}$, concentrated by ultrafiltration, and chromatographed on a BioGel A-0.5m column (Bio-Rad Laboratories, Richmond, Calif.). ME was stored at $4^{\circ} \mathrm{C}$ where it was stable for several months. Electrophoresis in sodium dodecyl sulfate-polyacrylamide gel revealed a single protein peak. Final specific activity was $40,600 \mathrm{U} / \mathrm{mg}$.

Antisera to purified ME was prepared by subcutaneous injection of $500 \mu \mathrm{g}$ enzyme in complete Freund's adjuvant into New Zealand white rabbits three times at 1 -wk intervals. $1 \mathrm{wk}$ after the last injection, animals were bled for antisera. Double immunodiffusion revealed only one precipitation band of identity between purified $\mathrm{ME}$ and total rat liver homogenate.

The relative rate of hepatic $\mathrm{ME}$ synthesis was determined by intraperatoneal administration of $0.5 \mathrm{mCi}\left[{ }^{3} \mathrm{H}\right]$ leucine (ICN Nutritional Biochemicals; $40-50 \mathrm{mCi} / \mathrm{mmol}$ ) $45 \mathrm{~min}$ before killing. Livers were homogenized in $2-3$ vol $0.32 \mathrm{M}$ sucrose, 3 $\mathrm{mM} \mathrm{MgCl}_{2}$ and centrifuged at $100,000 \mathrm{~g}$ for $60 \mathrm{~min}$. The supernate (cytosol) was brought to $10 \mathrm{mM}$ Tris- $\mathrm{HCl}, \mathrm{pH} 7.6,1 \%$ Triton $\mathrm{X}-100$. Incorporation of $\left[{ }^{3} \mathrm{H}\right]$ leucine into total cytosolic protein was determined by precipitation with $20 \%$ (wt/vol) TCA. The precipitate was washed three times with $20 \%$ TCA and dissolved in $0.3 \mathrm{ml}$ of $88 \%$ formic acid. Incorporation of $\left[{ }^{3} \mathrm{H}\right]-$ leucine into malic enzyme was determined by adding enough antisera to $1.7 \mathrm{ml}$ of cytosol to precipitate all enzyme activity. Purified unlabeled malic enzyme was added to bring each sample up to $6,500 \mathrm{U}$. After $2 \mathrm{~h}$ of incubation at $30^{\circ} \mathrm{C}$, the sample was layered over a cushion of $1 \mathrm{M}$ sucrose, $10 \mathrm{mM}$ Tris$\mathrm{HCl}, \mathrm{pH} \mathrm{7.6,1 \%}$ Triton $\mathrm{X}-100$ and centrifuged at $10,000 \mathrm{~g}$ for $10 \mathrm{~min}$. Pellets were washed three times with $0.9 \%$ (wt/vol) sodium chloride and dissolved in $0.3 \mathrm{ml}$ of $88 \%$ formic acid. Both the TCA and immunoprecipitates were counted in $10 \mathrm{ml}$ of Aquasol (New England Nuclear, Boston, Mass.). Immunoprecipitate backgrounds were determined by reprecipitating the original sample with an equal amount of antisera and 6,500 $\mathrm{U}$ of unlabeled purified malic enzyme. (23). The relative rate of synthesis (RRS) was calculated from: percent RRS = (counts per minute in $\mathrm{ME}$ immunoprecipitate/counts per minute in TCA precipitate) $\times 100$.

Isolation of liver nuclei and determination of the nuclear $\mathrm{T}_{3}$ receptor content and affinity were carried out as previously described (24). Similarly, the ratio of isotopically labeled $T_{3}$ in nuclei and plasma was determined according to methods previously described (25). The concentration of radioimmunoassayable $\mathrm{T}_{3}$ was determined by the methods of Surks et al. (26). In preliminary experiments the concentration of $T_{3}$ in serum and livers of hypothyroid animals was determined by the procedures outlined by Surks and Oppenheimer (27).

Comparisons between groups were analyzed by the Student's $t$ test with two tails. Log dose-response curves were fitted to the Rodbard equation (28) by a computer program kindly provided by Dr. David Rodbard (National Institutes of Health). This program fits dose-response data to the four parameter logistic function proposed by Dr. Rodbard and supplies confidence intervals for each of the four parameters. Square deviations were pooled where appropriate; otherwise the SEM of groups were calculated from more precise formula (29). 


\section{RESULTS}

In preliminary experiments we noted that the induction of lipogenic enzymes by the high CHO diet was less marked in hypothyroid than in euthyroid animals (Fig. 1). Our initial findings prompted us to examine in detail the effect of high $\mathrm{CHO}$ diet over the entire range of thyroidal status, from severe hypothyroidism to extreme hyperthyroidism. Accordingly, hypothyroid animals were treated with daily intraperitoneal $\mathrm{T}_{3}$ for $7 \mathrm{~d}$. Half the animals received a high $\mathrm{CHO}$ diet during the last $4 \mathrm{~d}$ of the study whereas the remaining half were continued on a regular chow diet. The results of these studies are summarized in Figs. 2 and 3 and a compendium of the parameters derived from an analysis of the results is given in Table I. Inspection of Fig. 2 reveals that for both diets the level of enzyme rises as the dose of $T_{3}$ is increased until a plateau level is achieved. However, the maximal level of enzyme attained in the hyperthyroid state was greater in the CHO-treated animals than in animals on the regular diet. For three of the enzymes, ME, FAS, and 6PGD, the extent of excursion of the enzyme from the hypothyroid to the hyperthyroid level was similar on both diets. G6PD constitutes a striking exception since the excursion was $109 \mathrm{U} / \mathrm{mg}$ on the high $\mathrm{CHO}$ diet and only $22 \mathrm{U} / \mathrm{mg}$ on the regular diet. In fact, the activity of G6PD on a regular diet with maximal levels of administered $\mathrm{T}_{3}$ was less than the level in the hypothyroid animals on the high $\mathrm{CHO}$ diet.

Of particular interest was that the half-maximally effective dose of $T_{3}\left(D_{50}\right)$ was markedly decreased by administration of a high $\mathrm{CHO}$ diet. Thus, the ratio of the

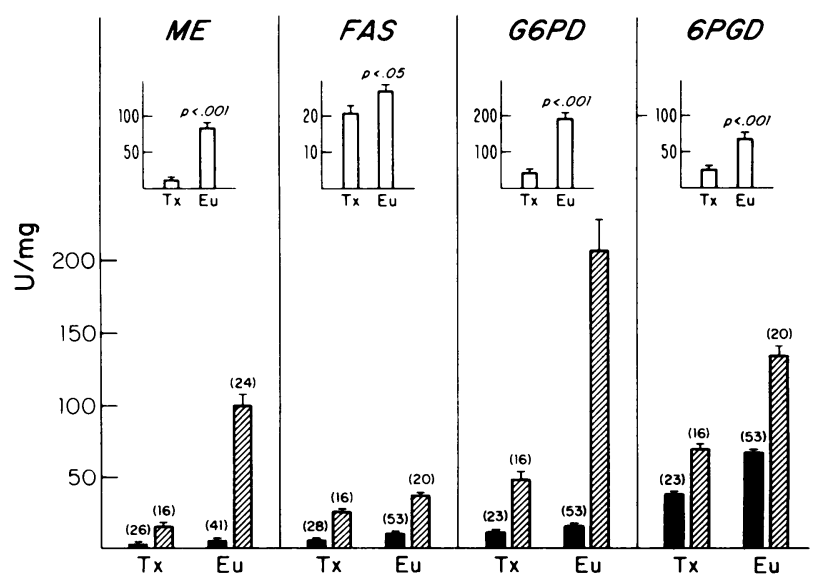

Figure 1 Influence of high CHO feeding on lipogenic enzyme induction in either thyroidectomized $(\mathrm{Tx})$ or euthyroid $(E u)$ rats. The bars represent the mean \pm SEM for each group, $n$ is in parenthesis. Animals were given the high $\mathrm{CHO}$ diet for $4 \mathrm{~d}$ before killing (hatched bar). The solid bar represents animals on a regular diet. The insert for each enzyme compares the increment induced by carbohydrate in Tx vs. Eu. The ordinate represents the enzyme specific activity.
$\mathrm{D}_{50}$ on the CHO diet to the $\mathrm{D}_{50}$ on a regular diet varied from 0.03 for FAS to 0.39 for ME. As a necessary consequence of the reduction in $\mathrm{D}_{50}$ by $\mathrm{CHO}$ feeding, the degree of amplification of the $T_{3}$ response was markedly reduced. As indicated in Fig. 2 and Table I the shift of the dose-response curve by the $\mathrm{CHO}$ diet leads to a virtual abolition of amplification. For ME the amplification factor on a regular diet $(f=13.1)$ is reduced to 2.5 , which represents an almost linear relationship between nuclear occupancy and enzyme induction. A comparable reduction in $\mathrm{f}$ values characterizes the other enzymes studied.

The reduction in $\mathrm{D}_{50}$ by the high $\mathrm{CHO}$ diet can be shown to be a reflection of the cooperative interaction between diet and $T_{3}$ in the induction of lipogenic enzymes. The degree of cooperativity can be quantitated from the ratio of the instantaneous slopes of the doseresponse curves to $T_{3}$ on the different diets (Appendix). Any ratio greater than one signifies a synergistic interaction. Values and ratios for the instantaneous slope at $\mathrm{D}=0.03 \mu \mathrm{g}$ are given in Table I. Since all the ratios were clearly above unity, these findings emphasize the cooperative interaction between $\mathrm{T}_{3}$ and $\mathrm{CHO}$ feeding in the induction of lipogenic enzymes.

The linear plot of the variables shown in Fig. 3 underscores the divergence in the initial slope on the two diets and thus, the cooperative relationship between $\mathrm{T}_{3}$ and $\mathrm{CHO}$ feeding. Moreover, inspection of the plot suggests that extrapolation of both curves appears to reach a common negative intercept on the abscissa, $-125 \mathrm{ng}$ $\mathrm{T}_{3} / \mathrm{d}, \sim^{1 / 3}$ the normal replacement value. If true, this is compatible with the hypothesis that the induction by $\mathrm{CHO}$ feeding in thyroidectomized animals is contingent on the presence of small residual quantities of thyroid hormone. To test this hypothesis we extracted $T_{3}$ from the liver and plasma of two thyroidectomized animals that had undergone complete arrest of growth. The material was concentrated and measured by radioimmunoassay in two dilutions. The livers contained 1.4 and $1.5 \mathrm{ng} \mathrm{T}_{3} / \mathrm{g}$ and two simultaneously extracted

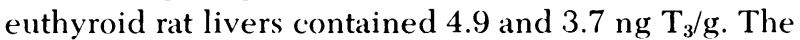
corresponding plasma $\mathrm{T}_{3}$ in the pooled thyroidectomized plasma was $0.23 \mathrm{ng} \mathrm{T}_{3} / \mathrm{ml}$, whereas in the euthyroid animal the concentration was $0.6 \mathrm{ng} \mathrm{T}_{3} / \mathrm{ml}$. These results indicate that the thyroidectomized rats used in our studies may have as much as one-third the normal circulating tissue and plasma concentration of $\mathrm{T}_{3}$.

Before considering the possible mechanisms responsible for the interaction between $\mathrm{T}_{3}$ and $\mathrm{CHO}$ feeding, studies were undertaken to ascertain whether the dietary induction of lipogenic enzyme activity was due to an increase in appearance rate or a decrease in fractional disappearance of the enzyme. For this purpose we measured the fractional rate of decrease in enzyme activity following the substitution of a regular diet to rats that had been on a high CHO diet the 

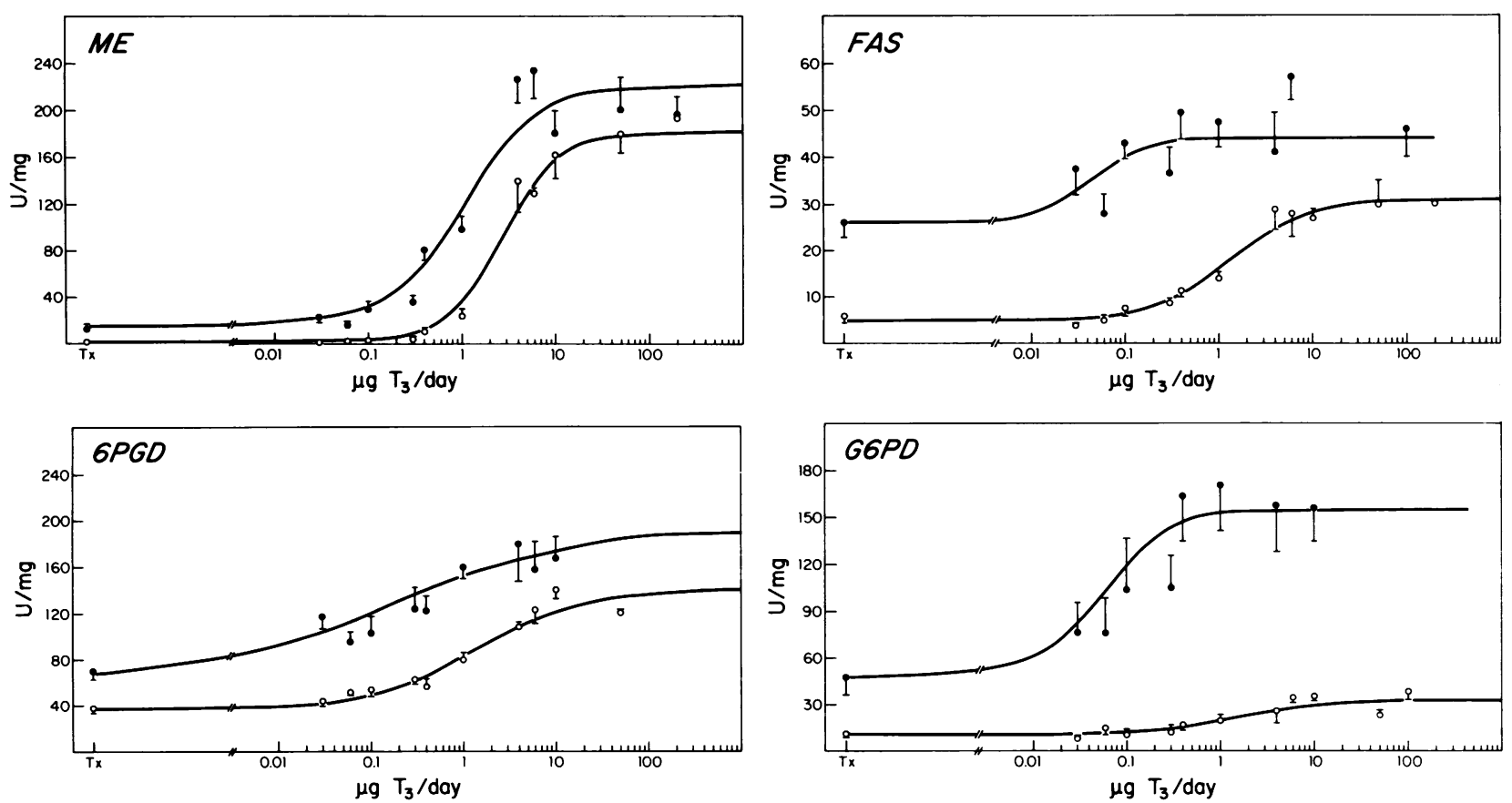

FIGURE 2 Complete dose-response relationship of lipogenic enzymes to $\mathrm{T}_{3}$ on regular and high CHO diets. Thyroidectomized rats were given graded doses of $T_{3}$ for $7 \mathrm{~d}$ and either given a high carbohydrate diet (closed circles) or left on a regular diet (open circles) for the last $4 \mathrm{~d}$. Each point represents the mean $\pm S E M$ of at least four animals (except only one rat at $200 \mu \mathrm{g}$ on a regular diet for $\mathrm{ME}$ and FAS). The line drawn is the computer generated best fit curve for the data.

previous $4 \mathrm{~d}$. A semilogarithmic plot of the enzyme level as a function of time indicated an apparent half-life of decline of $3.8 \mathrm{~d}$ for ME, $3.8 \mathrm{~d}$ for 6PGD, $2.6 \mathrm{~d}$ for G6PD, and $0.9 \mathrm{~d}$ for FAS. These values are similar to

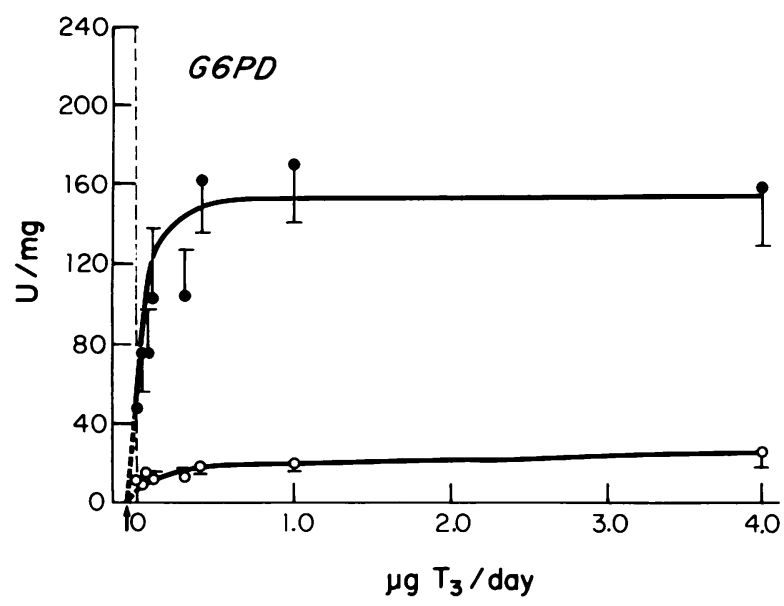

FIGURE 3 Low dose-response relationships of G6PD to $T_{3}$ administration on regular and high $\mathrm{CHO}$ diets. Data from Fig. 2 are plotted on linear coordinates up to a dose of $4 \mu \mathrm{g}$ $\mathrm{T}_{3} / \mathrm{d} / 100 \mathrm{~g}$ body wt. Symbols and curves are as in Fig. 2. Extrapolation to the abscissa (arrow) intercepts at a common value of $-125 \mathrm{ng} \mathrm{T}_{3} / \mathrm{d}$. Similar steep initial curves characterize plots of the other enzymes. previously observed values after discontinuation of $T_{3}$ treatment (15). This would suggest that for each enzyme the same limiting factor, probably the half-life of the enzyme itself, determines its fractional disappearance rate after withdrawal of either stimulus.

We next examined the potential mechanisms which might account for the observed interaction between dietary and hormonal stimuli. First, we considered the possibility that the high $\mathrm{CHO}$ diet might potentiate the effect of thyroid hormones either by decreasing the metabolic clearance rate of $T_{3}$ or by increasing the number or affinity of the $T_{3}$ nuclear receptor sites. Measurements of the $T_{3}$ clearance rate of isotopically injected $\mathrm{T}_{3}$ in euthyroid animals using noncompartmental methods (30) (Table II), however, showed only a $12 \%$ reduction by $\mathrm{CHO}$ feeding. This change is of uncertain significance and under any circumstance could not account for the observed dietary-induced events. Direct measurements of the binding capacity and affinity of isolated nuclei both in hypothyroid and euthyroid animals failed to reveal significant differences attributable to diet (Table II). Moreover, in vivo measurements of the nuclear/plasma ratio of $\mathrm{T}_{3}$ showed no substantial differences. Thus, there is no evidence favoring an increase in overall strength of nuclear binding as a consequence of $\mathrm{CHO}$ feeding.

Next, we considered the possibility that the induction 
TABLE I

Compendium of Dose-Response Parameters

\begin{tabular}{|c|c|c|c|c|c|c|}
\hline Enzyme & Diet & $\mathrm{E}_{\max }$ & $\mathrm{f}$ & b & $D_{50}$ & $\begin{array}{l}\text { Slope at } \\
\mathrm{D}=0.03 \mu \mathrm{g}^{*}\end{array}$ \\
\hline & & & & & $\mu g$ & \\
\hline \multirow[t]{3}{*}{ ME } & Regular & 180.4 & 13.1 & 1.47 & 2.8 & 11.2 \\
\hline & High $\mathrm{CHO}$ & 209.3 & 2.5 & 1.07 & 1.1 & 151.4 \\
\hline & High $\mathrm{CHO} /$ Regular & & & & & 13.5 \\
\hline \multirow[t]{3}{*}{ FAS } & Regular & 26.5 & 6.0 & 1.02 & 1.4 & 17.2 \\
\hline & High CHO & 17.8 & 1.7 & 1.51 & 0.043 & 173.9 \\
\hline & High $\mathrm{CHO} /$ Regular & & & & & 10.1 \\
\hline \multirow[t]{3}{*}{ G6PD } & Regular & 22.0 & 4.2 & 0.85 & 1.4 & 22.2 \\
\hline & High CHO & 108.7 & 0.7 & 1.19 & 0.057 & 881.1 \\
\hline & High CHO/Regular & & & & & 39.7 \\
\hline \multirow[t]{3}{*}{ 6PGD } & Regular & 102.1 & 3.5 & 0.77 & 1.44 & 122.1 \\
\hline & High CHO & 122.6 & 1.8 & 0.47 & 0.18 & 464.3 \\
\hline & High CHO/Regular & & & & & 3.8 \\
\hline
\end{tabular}

Abbreviations used in this table: $\mathrm{b}$, Hill coefficient (see Appendix); $\mathrm{E}_{\max }$, maximum response above a hypothyroid baseline; $\mathrm{f}$, amplification factor (see Text) $=[$ Hyperthyroid $-\mathrm{Tx} /$ Euthyroid - Tx].

* Calculated from Eq. 2 (Appendix).

of lipogenic enzymes was mediated exclusively by the high CHO dietary factor and that the effects of $\mathrm{T}_{3}$ could be explained simply by an enhanced generation of this factor. Since the maximal effects of thyroid hormonemediated events are characterized by a delay of many hours after the injection of hormone, one might then anticipate that the lag time for ME induction after the administration of a maximal intravenous dose of $\mathrm{T}_{3}$ would be substantially longer than the lag time after a pulse gavage of the high $\mathrm{CHO}$ diet. To evaluate the time of onset of $\mathrm{ME}$ induction by $\mathrm{T}_{3}$ or $\mathrm{CHO}$ feeding the relative rates of synthesis of $\mathrm{ME}$ were determined $45 \mathrm{~min}$ after the administration of $\left[{ }^{3} \mathrm{H}\right]$ leucine. The results of these studies are illustrated in Fig. 4 and clearly show that the increased rate of synthesis of $\mathrm{ME}$ after both stimuli begins at $\sim 2 \mathrm{~h}$ after administration

TABLE II

Effect of Diet on $T_{3}$ Metabolism and $T_{3}$ Nuclear Binding

\begin{tabular}{|c|c|c|}
\hline & High CHO diet & Regular diet \\
\hline MCR & $14.7 \mathrm{ml} / \mathrm{h} / 100 \mathrm{~g}$ & $16.8 \mathrm{ml} / \mathrm{h} / 100 \mathrm{~g}$ \\
\hline Half-life & $6.2 \mathrm{~h}$ & $7.6 \mathrm{~h}$ \\
\hline$\left[\frac{\text { Nuclear }}{\text { Plasma }}\right] *$ & $0.387 \pm 0.009$ & $0.361 \pm 0.023$ \\
\hline $\begin{array}{l}\text { Maximum nuclear } \mathrm{T}_{3} \\
\text { binding Eu }\end{array}$ & $0.32 \pm 0.03 \mathrm{ng} \mathrm{T}_{3} / \mathrm{mg} \mathrm{DNA}$ & $0.31 \pm 0.02 \mathrm{ng} \mathrm{T}_{3} / \mathrm{mg}$ DNA \\
\hline $\begin{array}{l}\text { Equilibrium association } \\
\text { constant } \mathrm{Eu}\end{array}$ & $6.2 \pm 0.1 \times 10^{8} \mathrm{M}^{-1}$ & $7.7 \pm 0.5 \times 10^{8} \mathrm{M}^{-1}$ \\
\hline $\begin{array}{l}\text { Maximum nuclear } T_{3} \\
\text { binding } T_{x}\end{array}$ & $0.56 \pm 0.02 \mathrm{ng} \mathrm{T}_{3} / \mathrm{mg} \mathrm{DNA}$ & $0.61 \pm 0.02 \mathrm{ng} \mathrm{T}_{3} / \mathrm{mg}$ DNA \\
\hline $\begin{array}{l}\text { Equilibrium association } \\
\text { constant } T_{x}\end{array}$ & $1.4 \pm 0.1 \times 10^{9} \mathrm{M}^{-1}$ & $1.2 \pm 0.1 \times 10^{9} \mathrm{M}^{-1}$ \\
\hline
\end{tabular}

Abbreviations used in this table: Eu, euthyroid rats, $n=4$; MCR, metabolic clearance rate of $\mathrm{T}_{3}$ determined from average plasma values in six rats on each diet; Reg, regular diet; Tx, thyroidectomized rats, $n=5$.

* Nuclear/plasma ratios of $\mathrm{T}_{3} 30 \mathrm{~min}$ after intravenous injection. $n=4$ for each diet at both $\mathrm{T}_{3}$ tracer and $\mathrm{T}_{3}$ load injections. Values are mean $\pm \mathrm{SEM}$. 


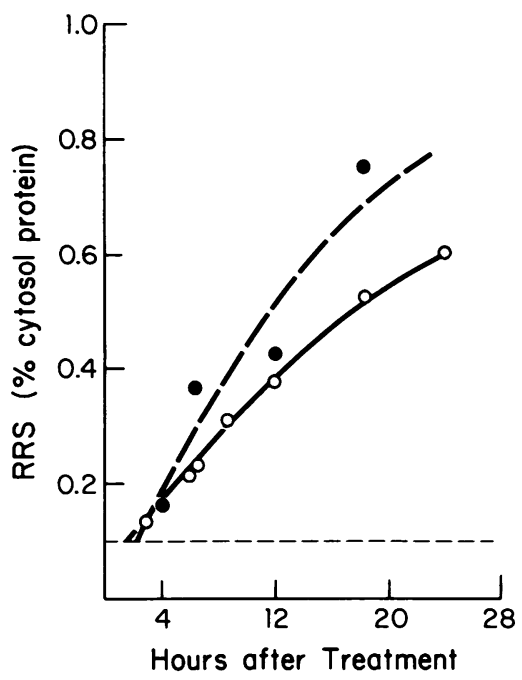

FIGURE 4 Relative rate of synthesis (RRS) of ME after either $\mathrm{T}_{3}$ or high CHO administration. Rats were given $\mathrm{T}_{3}(200 \mu \mathrm{g} /$ $100 \mathrm{~g}$ body wt i.v.) or gavaged with high $\mathrm{CHO}$ diet at $\mathrm{t}=0$ and given $0.5 \mathrm{mCi}\left[{ }^{3} \mathrm{H}\right] \mathrm{leu}$ i.p. $45 \mathrm{~min}$ before killing. The counts per minute in immunoprecipitable $\mathrm{ME}$ are compared to the cpm in TCA-precipitable cytosol as a function of time after the stimulus. Open circles are $\mathrm{T}_{3}$-induced rats, closed circles are $\mathrm{CHO}$ induced rats. Each point is the mean of two separate rats. The range at each point is no more than $\pm 15 \%$. The horizontal dashed line represents the RRS of untreated base-line rats $(\mathrm{RRS}=0.10 \% \pm 0.006, n=6)$.

of both stimuli. These results, in conjunction with the lack of effect of high CHO diet on $\mathrm{T}_{3}$ metabolism and receptor binding provide no support for the hypothesis that either the CHO diet or $\mathrm{T}_{3}$ is in any sense "primary" with respect to the other. Additional studies indicated that $24 \mathrm{~h}$ after the institution of the high $\mathrm{CHO}$ diet the relative rate of synthesis was shown to be eightfold increased above baseline values, proportional to the increase in the steady-state $\mathrm{ME}$ activity. The augmented synthesis rate could thus completely account for the increase in ME levels.

To determine whether or not synergism also characterizes the interaction of $\mathrm{CHO}$ and $\mathrm{T}_{3}$ in other tissues, studies were carried out with epididymal fat. The level of lipogenic enzymes was determined in hypothyroid, euthyroid and hyperthyroid animals (Table III). Of the four lipogenic enzymes studied only the response of $\mathrm{ME}$ was synergistic to $\mathrm{T}_{3}$ and $\mathrm{CHO}$ feeding. Thus, the increment in $\mathrm{ME}$ activity produced by $\mathrm{CHO}$ feeding in hypothyroid animals was only $10 \mathrm{U} / \mathrm{mg}$, whereas in euthyroid animals the increase was $140 \mathrm{U} /$ mg. Failure to demonstrate a cooperative interaction with the other lipogenic enzymes may have been due to the large experimental error encountered. A limited number of studies were performed with heart, kidney, and brain. No consistent evidence of induction either by $\mathrm{CHO}$ feeding or $\mathrm{T}_{3}$ administration was noted.

\section{DISCUSSION}

A number of recent reports have suggested the potential importance of the interaction of $\mathrm{T}_{3}$ with other hormones in producing specific biologic effects. Thus, two groups have studied the interrelationship of $\mathrm{T}_{3}$, growth hormone and steroids in the induction of $\alpha_{2 \mathrm{U}^{-}}$ globulin, an hepatic protein of unknown function found in male rats $(31,32)$. This interaction appears to occur predominately at a pretranslational level. Similarly, $\mathrm{T}_{3}$ and cortisol interact synergistically in the induction of the specific mRNA for growth hormone in $\mathrm{GH}_{1}$ cells, a cell line derived from a rat pituitary tumor (33). Results of the present series of experiments emphasize the physiologic relevance of the interaction of $T_{3}$ with other stimuli. Thus, we have shown the induction of lipogenic enzymes by the high $\mathrm{CHO}$ diet is closely related to the thyroidal status of the animal and conversely, the effect of $T_{3}$ in stimulating lipogenic enzymes is strongly influenced by dietary factors.

The degree of interaction of $\mathrm{T}_{3}$ with the high $\mathrm{CHO}$ diet varied with each of the lipogenic enzymes examined. The strongest degree of interaction occurred with G6PD. As illustrated in Fig. 2 for G6PD, a high CHO diet increases the sensitivity of $\mathrm{T}_{3}$ induction 40-fold over that on a regular diet. The minimal $T_{3}$ induction on normal chow raises the interesting possibility that other thyroid-dependent activities may not be apparent until the appropriate physiological or hormonal stimuli are applied.

Our findings also touch on the fundamental question as to whether thyroid hormone constitutes an absolute or only a relative requirement for the induction of lipogenic enzymes. Inspection of Fig. 3 raises the possibility that the carbohydrate induction observed in hypothyroid animals may be attributed to residual tissue $T_{3}$. Measurement of the $T_{3}$ concentration in liver and plasma in animals subjected to combined thyroidectomy and ${ }^{131}$ I treatment showed that the pool size of $T_{3}$ was approximately one-third that observed in normal animals. Further studies are required to determine whether the residual $T_{3}$ in these animals is due to incomplete thyroidectomy, extrathyroidal $T_{3}$ formation or an unsuspected dietary source of hormone. Regardless of the eventual resolution of this problem, the steep initial slope and early plateau noted in Fig. 3 points to the potential importance of "permissive" effects of $T_{3}$, which can easily be overlooked if animals are not made sufficiently hypothyroid.

Our studies have also clarified several aspects governing the interaction of $\mathrm{T}_{3}$ and the high $\mathrm{CHO}$ diet. Our findings effectively exclude the possibilities that $\mathrm{CHO}$ feeding either decreases the metabolic clearance rate of $T_{3}$ or enhances $T_{3}$-nuclear binding (Table II). Furthermore, we have shown that $T_{3}$ does not act exclusively by altering carbohydrate metabolism since the onset of 
TABLE III

Lipogenic Enzymes in Epididymal Fat*

\begin{tabular}{|c|c|c|c|c|}
\hline & ME & FAS & G6PD & 6PGD \\
\hline $\mathbf{T} \mathbf{x}$ & $10.2 \pm 7.0$ & $7.4 \pm 1.6$ & $52.6 \pm 4.8$ & $19.7 \pm 4.7$ \\
\hline $\mathrm{Tx}+\mathrm{CHO}$ & $20.3 \pm 4.4$ & $59.9 \pm 5.5$ & $87.6 \pm 13.0$ & $53.8 \pm 7.5$ \\
\hline$\Delta \mathrm{T} \times$ & $10.1 \pm 8.5$ & $52.5 \pm 5.7$ & $35.0 \pm 13.9$ & $34.1 \pm 8.9$ \\
\hline $\mathrm{Eu}$ & $51.8 \pm 19.0(12)$ & $24.2 \pm 6.7$ & $90.5 \pm 7.2$ & $51.5 \pm 7.2$ \\
\hline $\mathrm{Eu}+\mathrm{CHO}$ & $192.4 \pm 41.2(8)$ & $74.7 \pm 10.7$ & $103.5 \pm 10.4$ & $74.8 \pm 17.4$ \\
\hline$\Delta \mathrm{Eu}$ & $140.6 \pm 45.4$ & $50.5 \pm 12.6$ & $13.0 \pm 12.6$ & $23.3 \pm 18.8$ \\
\hline Hyper & $87.4 \pm 26.7$ & $35.8 \pm 11.2$ & $79.5 \pm 8.3$ & $54.6 \pm 6.8$ \\
\hline Hyper + CHO & $334 \pm 47.5$ & $86.2 \pm 6.7$ & $140.2 \pm 30.2$ & $99.7 \pm 10.5$ \\
\hline$\Delta$ Hyper & $246.6 \pm 54.5$ & $50.4 \pm 13.1$ & $60.7 \pm 31.3$ & $45.1 \pm 12.5$ \\
\hline
\end{tabular}

Abbreviations used in this table: + CHO, high CHO diet given $4 \mathrm{~d}$ before killing; Eu, euthyroid; hyper, $15 \mu \mathrm{g} \mathrm{T} / 100 \mathrm{~g} \mathrm{BW}$ intraperitoneal for $7 \mathrm{~d}$; Tx, thyroidectomized.

* Values are mean $\pm \mathrm{SEM}, n=4$ except where indicated in parenthesis.

$\$ \Delta$, carbohydrate induced increase in activity. Statistics compare $\Delta E u$ and $\Delta$ hyper to the $\Delta \mathrm{Tx}$ value. Differences are not significant except $\Delta \mathrm{Eu}$ for $\mathrm{ME}(P<0.025)$ and $\Delta \mathrm{Hyper}$ for $\mathrm{ME}(P<0.005)$.

induction by $\mathrm{T}_{3}$ or CHO feeding is simultaneous (Fig. 4). Thus, it appears reasonable to conclude that there is a common point of interaction of $T_{3}$ and the high $\mathrm{CHO}$ factor and that neither stimulus is primary to the other.

Recent studies in our laboratory have indicated that the induction of $\mathrm{ME}$ either by $\mathrm{CHO}$ or by $\mathrm{T}_{3}$, individually or in combination, is proportional to the level of mRNA for ME as measured by a translational reticulocyte lysate assay (6). Since there is general agreement that $T_{3}$ induces protein synthesis at a nuclear receptor level (13) we can infer that the signal created by the $\mathrm{T}_{3}$ receptor complex interacts with the signal generated by the high carbohydrate diet at a pretranslational level.

The nature of the carbohydrate-induced signal has not been defined. Previous studies have shown that in diabetic rats neither $\mathrm{CHO}$ nor $\mathrm{T}_{3}$ can effectively induce lipogenic enzymes (34). Nevertheless, the block created by insulin lack can be overcome by fructose which enters the liver via fructokinase (35). Furthermore, in other experiments from our laboratory ${ }^{2}$ synergism between $T_{3}$ and fructose has also been demonstrated in diabetic rats. Thus, it appears that the most proximal signal for $\mathrm{CHO}$ induction of $\mathrm{ME}$ is not insulin itself but probably an intermediate of $\mathrm{CHO}$ metabolism or a signal generated by such an intermediate.

We have previously shown in animals maintained on a regular diet that the rate of induction of $\mathrm{ME}$ is not related in a linear fashion to the nuclear occupancy

\footnotetext{
${ }^{2}$ Kaiser, F. E., N. Mariash, H. L. Schwartz, and J. H. Oppenheimer. Inhibition of malic enzyme induction by triodothyronine in the diabetic rat. Reversal by fructose feeding. Metab. Clin. Exp. In press.
}

by $\mathrm{T}_{3}$ but that the relationship which exists is strongly amplified. When the $T_{3}$-nuclear sites are fully saturated, the rate of induction is 14 -fold greater than when the sites are half saturated. The results of the current experiments indicate that when the animals are fed a high $\mathrm{CHO}$ diet the relationship between nuclear occupancy and response becomes almost linear in nature. The following and admittedly speculative explanation can be advanced. It is possible that in addition to the primary effects of $T_{3}$ on lipogenic enzyme induction discussed above, continued administration of $\mathrm{T}_{3}$ eventually results in increased turnover of $\mathrm{CHO}(36-38)$ leading to an enhanced formation of the putative intermediate responsible for the induction of lipogenic enzymes. On a regular diet with increased occupancy of the $T_{3^{-}}$ nuclear sites and an increased rate of generation of the intermediate the interaction of the two systems would result in an exponential increase in the rate of induction of lipogenic enzymes. On the other hand, with the high CHO diet one might expect a maximal formation of the putative intermediate. This would result in a simple linear increase in the rate of induction of $\mathrm{ME}$ as the $\mathrm{T}_{3^{-}}$ nuclear sites become progressively occupied (see Appendix for a formal exposition). Alternatively, it is conceivable that the hyperthyroid state serves to reduce the concentration of an inhibitor of lipogenesis. A high CHO diet could also result in a decrease in such an inhibitor.

The interaction of thyroid hormones and $\mathrm{CHO}$ metalorlism has received considerable attention in recent years. The conversion of $T_{4}$ to $T_{3}$ is inhibited (39) and the induction of ME is blocked with starvation (40). It is therefore of interest to ask whether the decrease in lipogenic enzyme induction by $T_{3}$ in starvation is the 
mirror image of the enhanced induction by $\mathrm{T}_{3}$ observed in the present set of experiments with a high $\mathrm{CHO}$ diet. Alterations in $T_{3}$ levels, nuclear $T_{3}$ receptor concentration and postreceptor factors may have an important regulatory function with respect to lipogenic enzyme induction. The cessation of lipogenesis in starvation and its resumption with $\mathrm{CHO}$ availability clearly represent an important adaptive biological process. The interaction of $\mathrm{T}_{3}$ with a high CHO diet may also be a generally useful physiological model for the study of the interaction of $\mathrm{T}_{3}$ with other biological processes.

\section{APPENDIX}

Derivation of the slope of the dose-response curve. The four parameter logistic function proposed by Rodbard (28) to describe dose-response data can be rearranged to:

$$
E=\frac{E_{\max } \cdot D^{b}}{\left(D_{50}\right)^{b}+D^{b}},
$$

where $\mathrm{E}$ is the incremental enzyme response, $\mathrm{E}_{\max }$ is the maximal incremental enzyme response, $D$ is the dose administered, $D_{50}$ is the dose which gives $50 \%$ of the maximum response, and $b$ is the Hill coefficient.

Differentiating $E$ with respect to $D$ yields:

$$
\frac{d E}{d D}=\frac{b \cdot E_{\max } \cdot D^{b-1}}{D_{50} b+2 D^{b}+D^{2 b} / D_{50}^{b}},
$$

from which the instantaneous slope of the dose-response curve can be obtained for any dose. Substitution of the computer generated values of the dose-response data into Eq. 2 allows one to easily determine whether any dietary manipulation produces a synergistic relationship with $T_{3}$ for any dose of $T_{3}$.

Mechanism of $T_{3}$ amplification. The model proposed in the Discussion holds that the generation of ME mRNA is proportional to the product of the concentrations of the $T_{3}$ nuclear receptor complex $\left(\mathrm{T}_{3} \mathrm{~N}\right)$ and the postulated carbohydrate-induced factor $(\phi)$ :

$$
\text { mRNA }=\alpha\left(\mathrm{T}_{3} \mathrm{~N}\right)(\phi),
$$

where $\alpha$ is a proportionality constant. This model further implies that when the animal is on a regular diet, $T_{3}$ directly influences one or more sequential steps in the generation of $\phi$. If each step is linearly related to $\left(\mathrm{T}_{3} \mathrm{~N}\right)$, then

$$
\phi=\beta\left(\mathrm{T}_{3} \mathrm{~N}\right)^{\mathrm{n}},
$$

where $\beta$ is another proportionality constant and $\mathrm{n}$ is the number of steps influenced by $T_{3}$. Thus,

$$
\text { mRNA }=\alpha \beta\left(\mathrm{T}_{3} \mathrm{~N}\right)^{\mathrm{n}+1}
$$

Since $\left(\mathrm{T}_{3} \mathrm{~N}\right)=0.5$ in the euthyroid animal (24), and if $n=3$, then it follows that the amplification factor $\left(16=(1)^{4} /(0.5)^{4}\right)$ would approximate previous values on a regular diet (14). On the other hand, if the high $\mathrm{CHO}$ diet produces maximal quantities of $\phi$ independent of $\left(T_{3} N\right)$, then Eq. 3 would predict that the $M E$ response would be linearly related to $\left(T_{3} N\right)$ with an amplification factor of $\sim 2$. Differences in $\phi$ and $n$ for each of the lipogenic enzymes could account for variable degrees of amplification.

\section{ACKNOWLEDGMENTS}

We thank Dr. David Rodbard of the National Institutes of Health for supplying us with his computer programs for the analysis of the dose-response relationship, Dr. Christopher Bingham of the Department of Applied Statistics, University of Minnesota for help in the statistical analysis of our data, and Mr. George Runger of the same department for computer programming and very useful discussions. The technical assistance of Robert Gunville and Ana Martinez, as well as the secretarial assistance of Betty Sokolosky and Nancy Rutledge are gratefully acknowledged.

This work was supported by National Institutes of Health grants AM-19812 and National Service Research Training grant AM-07203.

\section{REFERENCES}

1. Gibson, D. M., R. T. Lyons, D. F. Scott, and Y. Muto. 1972. Synthesis and degradation of the lipogenic enzymes of rat liver. Adv. Enzyme Regul. 10: 187-204.

2. Garcia, D. R., and D. Holten. 1975. Inhibition of rat liver glucose-6-phosphate dehydrogenase synthesis by glucagon. J. Biol. Chem. 250: 3960-3965.

3. Volpe, J. J., and P. R. Vagelos. 1976. Mechanisms and regulation of biosynthesis of saturated fatty acids. Physiol. Rev. 56: 339-417.

4. Winberry, L., and D. Holten. 1977. Rat liver glucose-6-P dehydrogenase: Dietary regulation of the rate of synthesis. J. Biol. Chem. 252: 7796-7801.

5. Hutchison, J. S., and D. Holten. 1978. Quantitation of messenger RNA levels for rat liver 6-phosphogluconate dehydrogenase. J. Biol. Chem. 253: 52-57.

6. Towle, H. C., C. N. Mariash, and J. H. Oppenheimer. 1980. Changes in the hepatic messenger ribonucleic acid for malic enzyme during induction by thyroid hormone or diet. Biochemistry. 19: 579-585.

7. Nepokroeff, C. M., and J. W. Porter. 1978. Translation and characterization of the fatty acid synthetase messenger RNA. J. Biol. Chem. 253: 2279-2283.

8. Flick, P. K., J. Chen, A. W. Alberts, and P. R. Vagelos. 1978. Translation of rat liver fatty acid synthetase mRNA in a cell-free system derived from wheat germ. Proc. Natl. Acad. Sci. U. S. A. 75: 730-734.

9. Diamant, S., E. Gorin, and E. Shafrir. 1972. Enzyme activities related to fatty-acid synthesis in liver and adipose tissue of rats treated with triiodothyronine. Eur. J. Biochem. 26: 553-559.

10. Kumar, S., D. K. Das, A. E. Dorfman, and N. Asato. 1977. Stimulation of the synthesis of hepatic fatty acid synthesizing enzymes of hypophysectomized rats by $3,5,3^{\prime}-\mathrm{L}$ triiodothyronine. Arch. Biochem. Biophys. 178: 507-516.

11. Volpe, J. J., and J. C. Marasa. 1975. Hormonal regulation of fatty acid synthetase, acetyl-CoA carboxylase and fatty acid synthesis in mammalian adipose tissue and liver. Biochim. Biophys. Acta. 380: 454-472.

12. Roncari, D. A. K., and V. K. Murthy. 1975. Effects of thyroid hormones on enzymes involved in fatty acid and glycerolipid synthesis: Evidence for tissue specificity. J. Biol. Chem. 250: 4134-4138.

13. Oppenheimer, J. H. 1979. Thyroid hormone action at the cellular level. Science (Wash. D. C.). 203: 971-979.

14. Oppenheimer, J. H., P. Coulombe, H. L. Schwartz, and N. W. Gutfeld. 1979. Nonlinear (amplified) relationship 
between nuclear occupancy and triiodothyronine and the appearance rate of hepatic $\alpha$-glycerophosphate dehydrogenase and malic enzyme in the rat. J. Clin. Invest. 61: 987-997.

15. Mariash, C. N., F. E. Kaiser, and J. H. Oppenheimer. 1980. Comparison of the response characteristics of four lipogenic enzymes to triiodothyronine administration: evidence for variable degrees of amplification of the nuclear- $\mathrm{T}_{3}$ signal. Endocrinology. 106: 22-27.

16. Rudack, D., E. M. Chisholm, and D. Holten. 1971. Rat liver glucose 6-phosphate dehydrogenase: Regulation by carbohydrate diet and insulin. J. Biol. Chem. 246: 12491254.

17. Rudack, D., E. M. Gozukara, E. M. Chisholm, and D. Holten. 1971. The effect of dietary carbohydrate and fat on the synthesis of rat liver 6-phospho-gluconate dehydrogenase. Biochim. Biophys. Acta. 252: 305-313.

18. Oppenheimer, J. H., E. Silva, H. L. Schwartz, and M. I. Surks. 1977. Stimulation of hepatic mitochondrial $\alpha$ glycerophosphate dehydrogenase and malic enzyme by Ltriiodothyronine: characteristics of the response with specific nuclear thyroid hormone binding sites fully saturated. J. Clin. Invest. 59: 517-527.

19. Bottomley, R. H., H. C. Pitot, V. R. Potter, and H. P. Morris. 1963. Metabolic adaptations in rat hepatomas $v$. reciprocal relationship between threonine dehydrase and glucose-6-phosphate dehydrogenase. Cancer Res. 23: 400-409.

20. Nepokroeff, C. M., M. R. Lakshmanan, and J. W. Porter. 1975. Fatty acid synthase from rat liver. Methods Enzymol. 35: $37-44$

21. Lowry, O. H., N. J. Rosebrough, A. L. Farr, and R. J. Randall. 1951. Protein measurement with the Folin phenol reagent. J. Biol. Chem. 193: 256-275.

22. Yeung, K. K., and R. J. Carrico. 1976. Purification of malic enzyme by affinity chromatography on immobilized $N^{6}$-(6-Aminohexyl)-Adenosine $2^{\prime}, 5^{\prime}$-biphosphate. Anal. Biochem. 74: 369-375.

23. Schimke, R. T., E. W. Sweeney, and C. M. Berlin. 1965. The roles of synthesis and degradation in the control of rat liver tryptophan pyrrolase.J. Biol. Chem. 24: 322-331.

24. Koerner, D., M. I. Surks, and J. H. Oppenheimer. 1974. In vitro demonstration of specific triiodothyronine binding sites in rat liver nuclei. J. Clin. Endocrinol. Metab. 38: 706-709.

25. Oppenheimer, J. H., H. L. Schwartz, and M. I. Surks. 1974. Tissue differences in the concentration of triiodothyronine nuclear binding sites in the rat: liver, kidney, pituitary, heart, brain, spleen and testis. Endocrinology. 95: 987-993.

26. Surks, M. I., A. R. Schadlow, and J. H. Oppenheimer. 1972. A new radioimmunoassay for plasma L-triiodothyronine: measurements in thyroid disease and in patients maintained on hormonal replacement. J. Clin. Invest. 51: 3104-3113.

27. Surks, M. I., and J. H. Oppenheimer. 1977. Concentra- tion of L-thyroxine and L-triiodothyronine specifically bound to nuclear receptors in rat liver and kidney: quantitative evidence favoring a major role of $T_{3}$ in thyroid hormone action. J. Clin. Invest. 60: 555-562.

28. Rodbard, D. 1974. Apparent positive cooperative effects in cyclic AMP and corticosterone production by isolated adrenal cells in response to ACTH analogues. Endocrinology. 94: 1427-1437.

29. Diem, K., editor. 1962. Documenta Geigy Scientific Tables. Geigy Pharmaceuticals, Div., Ciba-Geigy Corp., Ardsley, N. Y. Sixth edition. 172.

30. Oppenheimer, J. H., H. L. Schwartz, and M. I. Surks 1975. Determination of common parameters of iodothyronine metabolism and distribution in man by noncompartmental analysis. J. Clin. Endocrinol. Metab. 41: 319324.

31. Kurtz, D. T., and P. Feigelson. 1978. Multihormonal control of the messenger RNA for the hepatic protein $\alpha_{2 u}$ globulin. In Biochemical Actions of Hormones. G. Litwack. editor. Academic Press, Inc., New York. 5: 433-455.

32. Roy, A. K., and D. J. Donbenenko. 1977. Role of growth hormone in the multihormonal regulation of messenger


rats. Biochemistry. 16: 3918-3922.

33. Shapior, L. E., H. H. Samuels, and B. M. Yaffe. 1978. Thyroid and glucocorticoid hormones synergistically control growth hormone mRNA in cultured $\mathrm{GH}_{1}$ cells. Proc. Natl. Acad. Sci. U. S. A. 75: 45-49.

34. Ruegamer, W. E., G. H. Newman, D. A. Richert, and W. W. Westerfield. 1965. Specificity of the $\alpha$-glycerophosphate dehydrogenase and malic enzyme response to thyroid hormone. Endocrinology. 77: 707-715.

35. Volpe, J. J., and P. R. Vagelos. 1974. Regulation of mammalian fatty-acid synthetase. The roles of carbohydrate and insulin. Proc. Natl. Acad. Sci. U. S. A. 71: 889-893.

36. Glock, G. E., P. McLean, and J. K. Whitehead. 1956. Pathways of glucose catabolism in rat liver in alloxan diabetes and hyperthyroidism. Biochem. J. 63: 520-524.

37. Althausen, T. L. 1940. The disturbance of carbohydrate metabolism in hyperthyroidism. JAMA (J. Am. Med. Assoc.). 115: $101-104$.

38. Elrick, H., C. J. Hlad, and Y. Arai. 1961. Influence of thyroid function on carbohydrate metabolism and a new method for assessing response to insulin. J. Clin. Endocrinol. Metab. 21: 387-400.

39. Vagenakis, A. G., A. Burger, G. I. Portnay, M. Rudolph, J. T. O'Brian, F. Azizi, R. A. Arky, P. Nicol, S. H. Ingbar, and L. E. Braverman. 1975. Diversion of peripheral thyroxine metabolism from activating to inactivating pathways during complete fasting. J. Clin. Endocrinol. Metab. 41, 191-194.

40. Dillmann, W. H., H. L. Schwartz, and J. H. Oppenheimer. 1978. Selective alterations in hepatic enzyme response after reduction of nuclear triiodothyronine receptor sites by partial hepatectomy and starvation. Biochem. Biophys. Res. Commun. 80: 259-266. 